\title{
The Effect of Electronic Banking on Customer Services Delivery in Commercial Banks in Rwanda
}

\author{
Rose Nyiranzabamwita ${ }^{1} \&$ Jean Bosco Harelimana ${ }^{1, *}$ \\ ${ }^{1}$ Kigali Independent University (Ulk), Rwanda \\ *Correspondence: Kigali Independent University (Ulk), P.O.BOX.2280, Rwanda. E-mail: \\ info@ulk.ac.rw
}

Received: June 2, 2019 Accepted: August 2, 2019 Published: November 25, 2019

doi: 10.5296/erm.v5i1.15904 URL: https://doi.org/10.5296/erm.v5i1.15904

\begin{abstract}
The aim of the study was to assess how electronic banking affected customer delivery channels in Rwanda commercial banks. The specific objectives include assessing the effectiveness of e-banking, analyzing the factors affecting the customer delivery system, and also finding out the affiliation that exists between customer service delivery and e-banking in the bank of Kigali. Study participants included 1215 employee and about 350000 bank clients. The total number was 351215 study participants. The sample size was 400 , which included both the staff and clients. The study revealed that customer service delivery in Bank of Kigali was explained by the probability of 0.0374 for internet banking; by the probability of 0.0004 for mobile banking; by probability of 0.0010 for electronic tax and that are respectively expected to $3.74 \% \& 0.04 \%$ $\& 0.1 \%$ and of probabilities which are less than $10 \%$. If we consider the simple regression theory, there is a probability of less than $10 \%$ by each electronic banking factor, which represents functional fitness variability. The $\mathrm{R}^{2}$ is 0.969 , whereas the Adjusted $\mathrm{R}^{2}$ is 0.965 , which indicates estimated model goodness. Up to $96.9 \%$ of the long-run appreciation in customer service delivery is influenced by changes in internet banking; mobile banking; electronic tax as implemented by the organization. Hence, the study revealed of essential affiliation between electronic banking and the observed factors, and the customer delivery channel in Bank of Kigali. The study recommended on sensitization of clients on the utilization and advantages of electronic banking services through having public awareness programs that boost their knowledge of the service.
\end{abstract}

Keywords: Electronic Banking; Internet Banking; Mobile Banking; Electronic Tax; Customer Services Delivery; Customer satisfaction; Customer Preferences; Customer Perception 


\section{Introduction}

According to Taylor (2014) cited by Alexan (2015), some international monetary institutions implement electronic banking services to their customers. Such firms include commercial banks, financial cooperatives, and firms offering microfinance services, among others. The automated service is meant to provide adequate customer delivery channels. It is collectively approved that a safe and well-organized e-banking service use as an international technology system is crucial for secure banking institutions in different locations such as Europe, America, Asia, and Africa. The benefits derived from the information technology system, as well as electronic banking, are practical among users. The automated information technology system offers some benefits to the customers; it is convenient, secure, keeps records of transactions, and also maintains a low cost. Customer service delivery proves that the information technology system can eliminate or reduce the challenges users may encounter in services such as payment or any other financial settlement system.

The European Union (EU) has been involved in the usage and adoption of e-money since 2000, as well; for example, in France, England, and German implemented electronic banking much longer than many other countries of the same regions. Mobile financial services are a term used to collectively refer $t$ a range of financial services which the use of mobile phones can facilitate. The three financial services completed over mobile phones include money transfer, mobile payment, and also mobile banking. The Barclays Bank in the UK had commercial electronic where clients in any region of the country can send and receive money with the use of their mobile phones. The money is transferred electronically with their mobile phones. The service is also offered by the organization internationally or cross-borders (Barclays Bank, 2013).

In Africa, on behalf of financial institutions, the electronics implementation as well as internet banking services retail information technology system has been designed in a bid to help both the clients and the financial institutions in curbing some of the challenges experienced during the settlement and payment processes. South Africa, Ghana, and Nigeria, including Egypt, are the countries that have effective implementation of electronic banking in Africa more than others, and they present success results. These countries have adopted e-money over cash. The monetary value is stored in gadgets and is used in settling any payment or monetary value deal. There are various methods of storing e-money, such as cards, devices, or even the servers. For example, the pre-paid cards, electronic purses, which include the Kenyan MPESA system, or also web-based electronic stores such as PayPal. Therefore, e-money serves as an overall term for more specific electronic financial products and services (Saleh, 2014).

For the case of Rwanda, banking institutions, financial firms are making substantial technological investments in improving their setups in a bid to ensure the provision of new and essential electronic financial services. Some of these electronic web-based retail banking services are making small firms adopt the use of technology at relatively favorable costs (NBR, 2018).

Also, links that have been developed between cell phone and bank accounts of corporations and individuals. It has enabled customers to adopt the use of their cell phones as another banking channel. The services they enjoy through the use of mobile phones include deposits, 
withdrawals, fund transfers from one record to the other, settlement of bills, and also balance inquiry. Most of these mobile financial settlement services are additive in that they provide new delivery channels to their existing bank clients (NBR, 2018).

Despite the usage of computerized innovation in the financial division, banks continue to recognize the long queues as their clients are still using different branches of banks at a vast rate comparing to the previous one before the implementation of e-banking. Public awareness and willingness to adopt e-banking impacts its adequacy. Also, the speed of internet connection and its availability in different areas of the country affects the selection of web-based financial services. The financial sector is key to support the economy of the country as the availability of the financial inclusions increases savings; hence, economic growth. Banks in Rwanda are facing the above challenges as the result of a lack of access to remote financial inclusion. From this concept, there are some problems regarding customer satisfaction through financial inclusion associated with the banking sector arise. Among those questions, the use of remote financial inclusion and how it is connected with its success factors have a remarkable effect on customer service delivery in the banking sector. It shows the existence of a research gap that concerns the appropriate use of financial inclusion, especially electronic banking, in delivery of service in the banking sector that can be enhanced if the E-banking usage is used effectively and efficiently. Therefore, it is from previous issues that motivated the researcher to find out how electronic banking in Bank of Kigali has impacted on delivery the customer services.

\section{Objectives}

This study is aiming to assess the impacts of electronic banking towards customer services delivery of commercial banks in Rwanda.

The following are specific objectives of the study

1. To assess the effectiveness of electronic banking application in Bank of Kigali.

2. To analyze the determinants of customer services delivery in Bank of Kigali.

3. To find out the relationship among electronic banking and customer services delivery in Bank of Kigali

\section{Literature Review}

Salehi \& Zhila (2015), explain that the internet and World Wide Web development influenced banks to increase the use of electronic systems in receiving instructions as well as service and product delivery to their customers. This system of using the internet in financial services is termed as e-banking. However, there are various variety of items and services which banks provide electronically, with each system having its substance, capacity, and refinement.

E-banking is the conveyance of customary budgetary administrations to the clients electronically. The variation arises partially because electronic banking denotes any monetary 
services in which customers can acquire their bank details or information and perform on their own through the use of mobile phones or computers. According to Salehi \& Zhla (2015), e-banking is an electronic connection between a commercial facility, that is a bank, and the customers, which enable management and control of customers' finances.

There are some values which e-banking offers to its clients. For instance, a full range of services is made available at any time of the day to the customers, which include services which are not offered in some branches. Also, e-banking provides a significant advantage to the clients that have low costs, with some services free to clients. Price is an essential factor which seems to be influencing e-banking services (Sathye, 1999).

Mobile banking is any form of financial transaction which is carried out over a mobile phone. The activities range from bank sending fraud or even usage event which a client is notified over the phone, to complex transactions such as settling bills or sending money over long distances. Mobile banking offers an advantage in that a client can transact anywhere at any time of the day. However, some security concerns and some limited scope of capabilities compared to banking person offers some disadvantages of mobile banking. Many financial institutions are offering some mobile applications to their clients, which makes mobile banking very convenient. People choose mobile banking services due to their ability to check deposits, paying for a service or product offered, transferring money to another partner, or locating instant ATMs (Vaidya, 2011).

Electronic tax is an automated automatic payment process that some corporations and banks use. E-banking facilitates the whole automated tax process, from initiating the payment to the final settlement of the payment, which is free from any human intervention. E-banking comes for the aid of corporations and local businesses in that they pay taxes faster over the internet than the traditional queuing process (Charles, 2015).

Customer service delivery is ensuring customers' satisfaction through the use of a product or service. The facility must ensure clients' expectations, preferences, and perceptions are met. Customer service happens when a commercial facility is offering a service to the client, which includes purchases or returning a product. Customer service can happen through in-person interactions, making phone calls, the customer making self-services, or any other means. The process is essential in retaining a client and the relationships with the financial firms (Tandelilin et al, 2007).

Any commercial facility offering monetary services such as deposits and giving business loans is a commercial bank. Commercial banks can also refer to a bank that deals with corporations or businesses. The provision of financial services to the general public is the primary role of commercial banks. Similarly, economic and social stability is a role given to commercial banks. Therefore, creating and managing credits is another task of commercial banks (Alexan, 2015).

There are similar studies on the impacts of e-banking on client service delivery of banks. In the segment below, the study presents some of the studies related to the topic.

Bahia (2007), cited by Vla et al. (2013), gives evidence of cost reduction productivity gain, which technological advances in the financial sector have made in European banks. Similarly, 
operational costs in the Turkish retail banking sector are lowered while customer satisfaction and retention are increased through e-banking, as illustrated by Carlson E. \& Lang A. (2001). According to Meuter D. (2010), operating costs minimization and maximizing the revenues are the significant factors driving e-banking. Similarly, Ombati et al. (2011), IT is the ideal solution to the banking sector in reducing operating costs as well as enhancing information management, which makes banking more profitable.

Many sectors in the economy, inclusive of the financial industry, cannot avert technological advances. Banking over the internet is one of the technological advancement which has gained competition. The evolution of ATMs, e-banking, and mobile banking has increased competition among banks. New markets and distribution channels have also been created due to the penetration of the internet into other areas. Allen \& Strahan (2002) explain e-banking as giving financial services over the internet. In modern times, banks have started adopting various channels in delivery of services through using hybrid platforms where some branches offer both traditional and electronic banking services.

The CBK allowed some microfinance that takes deposits to operate agencies. Some of the mobile network operators and other financial institutions in Kenya have embraced this channel and opened multiple agencies throughout the country. One of the mobile operators in Kenya, Safaricom had more than 100000 agencies in the country by 2016 (Safaricom Annual Report, 2016). Similarly, over ten banks have connected more than 10,000 bank agents in the country since 2011. Two leading banks, namely Equity Bank and KCB Group, have been at the forefront in opening bank agents in the country. The vast number of agents across the country support their adoption of this distribution channel. The main objective of this channel is cutting down operational costs for the banks, with many scholars have researched e-banking.

Kigen (2010) sought to set up the exchange cost effect of mobile banking on banks. The study revealed reduced transaction charges. Lack of customer awareness of e-banking led to banks not yet feeling the transaction reduction. However, there has been a significant difference in the same. A study by Munaye (2009) sought to establish the impact of mobile banking as a strategic reaction to the external challenges of Equity bank limited. The report revealed that the effects of financial performance were not considered during the response.

A report by Mulee (2011) sought to establish how e-banking impacted the microfinance firms in Nairobi. The report failed to touch on mainstream banks in the country. The above studies reveal little studies on the financial impact which e-banking has on banks in Kenya. Hence, this study established how e-banking influenced commercial banks' monetary performance. The past studies have carried out researches on other fields, leaving out some challenges on e-banking unaddressed.

The previous studies have some gaps in commercial banks in which the research focused on filling through its findings.

However, the study revealed some adverse relationships between a customer's education level and how they are satisfied by e-banking services. There is additionally a negative connection between customers' fulfillment and satisfaction with e-banking services. Hence, literature 


\section{Macrothink

offers some negative relations in some sectors and even positive links in some areas of e-banking and customer service delivery. Nevertheless, the findings which can relate to the Rwandan case remain unclear, which is what the study aims to cover and give some recommendations on e-banking services in Rwanda.

\section{Methodology}

This section reveals the overall approach and process which the research took, starting with data collection and its analysis.

Data collection: The study applied the questionnaire, interview and documentary. The research population meant to give information that relates to research objectives is based on the Bank of Kigali employees. The complete number of employees is 1215 in various offices. Additionally, the bank customer were included, with a total of 350000 customers on Bank of Kigali being targeted during the survey. Therefore, the target population totals to 351215 participants. The sample size was determined using Yamane mathematical formula. Thus, the sample size for this study is 400 respondents, with staff and customers included. A simple random sample technique was used in determining the sample population.

Data analysis: A regression analysis model was presented through calculating, analyzing and interpreting the relationship which exists between the research variables. The internet banking (or IB); the mobile banking (or $\mathrm{MB}$ ) and the electronic tax (or ET); all as independent variables.

The independent research variables include Internet Banking (IB), Mobile Banking (MB), and also electronic tax (ET). The dependent variable include customer service delivery (CSD).

Bo is constant, while the parameters of equation are $\boldsymbol{\beta}_{1} ; \boldsymbol{\beta}_{2}$ and $\boldsymbol{\beta}_{3}$

The term error is $\boldsymbol{\varepsilon}_{\mathbf{t}}$. The values were particularly stated for the regression model used in the analysis stage, and presented below. $\mathbf{Y}$ (customer services delivery) $=\boldsymbol{\beta} \mathbf{0}+\boldsymbol{\beta}_{1}$ (internet banking) $+\boldsymbol{\beta}_{2}$ (mobile banking) $+\boldsymbol{\beta}_{\mathbf{3}}($ electronic tax $)+\boldsymbol{\varepsilon}$.

\section{$\log C S D=\beta_{0}+\beta_{1} \log I B_{t 1}+\beta_{2} \log M B_{t 2}+\beta_{3} \log E T_{t 3}+\varepsilon_{t} ;$}

The equation was set from the general model and the following;

$\mathrm{Y}=\beta_{0}+\beta_{1} X_{\mathrm{it} 1}+\beta_{2} \mathrm{X}_{\mathrm{iit} 2}+\beta_{3} \mathrm{X}_{\mathrm{iit} 3}+\varepsilon \mathrm{t}$

And/ or

$\log Y=\beta 0+\beta_{1} \log X_{\mathrm{it} 1}+\beta_{2} \log X_{\mathrm{iit} 2}+\beta_{3} \log X_{\mathrm{iiit} 3}+\varepsilon_{\mathrm{t}}$.

\section{Results, Discussions and Findings}

The section below shows the findings of the study. It also indicates some linked information that relates to the research questions. Besides, there is statistical data analysis using the SPSS 
23rd version.

Table 1. The Effects of Internet Banking Towards Customer Services Delivery

\begin{tabular}{|c|c|c|c|c|c|}
\hline \multirow[b]{2}{*}{ Views of respondents } & \multicolumn{2}{|l|}{ Mean } & \multicolumn{3}{|c|}{ Std Deviation } \\
\hline & $\begin{array}{l}\text { Statistical } \\
\text { range }\end{array}$ & $\begin{array}{l}\text { Results of } \\
\text { the mean }\end{array}$ & $\begin{array}{l}\text { Statistical } \\
\text { Scales }\end{array}$ & $\begin{array}{l}\text { Results of } \\
\text { Deviation }\end{array}$ & Std \\
\hline Saving time and security of funds & 4.71 & Very strong & .951 & $\begin{array}{l}\text { Positive and very } \\
\text { correlation }\end{array}$ & high \\
\hline $\begin{array}{l}\text { Holding a lot of financial data and } \\
\text { decreasing of financial costs }\end{array}$ & 4.72 & Very strong & .956 & $\begin{array}{l}\text { Positive and very } \\
\text { correlation }\end{array}$ & high \\
\hline $\begin{array}{l}\text { Reducing financial errors and easy } \\
\text { money transfer }\end{array}$ & 4.14 & Strong & .734 & $\begin{array}{l}\text { Positive and } \\
\text { correlation }\end{array}$ & high \\
\hline $\begin{array}{l}\text { Quick financial services and paperless } \\
\text { services }\end{array}$ & 3.99 & Strong & .713 & $\begin{array}{l}\text { Positive and } \\
\text { correlation }\end{array}$ & high \\
\hline $\begin{array}{l}\text { Increasing of financial profitability and } \\
\text { increasing the number of customers }\end{array}$ & 3.87 & Strong & .709 & $\begin{array}{l}\text { Positive and } \\
\text { correlation }\end{array}$ & high \\
\hline Overall of mean & 4.286 & Strong & -------- & -------- & \\
\hline
\end{tabular}

Source: Primary Data, 2019

The table shows the analysis of 5 items on how e-banking impacts the delivery of customer service. There was an overall mean of 4.286, which illustrates a reliable internet banking service by Bank of Kigali. On the first item of time and security of the funds, there was a mean of 4.71 and a high correlation standard deviation of 0.951. It shows that the clients strongly agree that e-banking saves their time as well as ensuring the security of their funds. Also, the second item about holding financial data and decreasing costs had a mean of 4.72 and a high correlation standard deviation of 0.956 . The third item centered on a reduction of financial errors as well as quick money transfers. The results showed a mean of 4.14 and a positive correlation with a standard deviation of 0.734 , which showed that respondents agreed that e-banking has fewer financial errors. The fourth item under study indicated quick financial and paperless services with a mean of 3.99 and positive relations with a standard deviation of 0.713 . The fifth item which the study examined showed there was increasing financial profits as well as several customers, which the respondents agreed on with a mean of 3.87 and a positive correlation with a standard deviation of 0.709 .

The study findings agree with Sathye (1999) results that indicated e-banking offers new customer value, making clients experience a new full range of services, which include some services not provided in the bank branches. The primary benefit of e-banking is its cost reduction ability. 


\section{Macrothink}

Table 2. The Effects of Mobile Banking Towards Customer Services Delivery

\begin{tabular}{|c|c|c|c|c|}
\hline \multirow[b]{2}{*}{ Views of respondents } & \multicolumn{2}{|l|}{ Mean } & \multicolumn{2}{|c|}{ Std Deviation } \\
\hline & Statistical range & $\begin{array}{l}\text { Results of the } \\
\text { mean }\end{array}$ & $\begin{array}{l}\text { Statistical } \\
\text { Scales }\end{array}$ & $\begin{array}{l}\text { Results of Std } \\
\text { Deviation }\end{array}$ \\
\hline $\begin{array}{l}\text { Saving time and security of } \\
\text { funds }\end{array}$ & 4.51 & Very strong & .934345 & $\begin{array}{l}\text { Positive and very } \\
\text { high correlation }\end{array}$ \\
\hline $\begin{array}{l}\text { Holding a lot of financial } \\
\text { data and decreasing of } \\
\text { financial costs }\end{array}$ & 4.99 & Very strong & .981144 & $\begin{array}{l}\text { Positive and very } \\
\text { high correlation }\end{array}$ \\
\hline $\begin{array}{l}\text { Reducing financial errors } \\
\text { and easy money transfer }\end{array}$ & 4.45 & Very strong & .926425 & $\begin{array}{l}\text { Positive and very } \\
\text { high correlation }\end{array}$ \\
\hline $\begin{array}{l}\text { Quick financial services } \\
\text { and paperless services }\end{array}$ & 2.75 & Neutral & .664069 & $\begin{array}{l}\text { Positive and high } \\
\text { correlation }\end{array}$ \\
\hline $\begin{array}{l}\text { Increasing of financial } \\
\text { profitability and increasing } \\
\text { the number of customers }\end{array}$ & 3.87 & Strong & .709 & $\begin{array}{l}\text { Positive and high } \\
\text { correlation }\end{array}$ \\
\hline Overall of mean & 4.175 & Strong & ------- & -------- \\
\hline
\end{tabular}

Source: Primary Data, 2019

Table 2 assesses the effects of mobile banking on customer service delivery. The first item on saving time and security of funds had a mean of 4.51 and a standard deviation of 0.934345 , which showed that customers strongly agreed that e-banking saved their time spent on banking. The second item, which was reducing financial costs, had a mean of 4.9 and a standard deviation of 0.981144 , which showed a positive correlation. The third item on reducing financial errors had a mean of 4.45 and a standard deviation of 926425 , which showed that customers agreed e-banking reduced mistakes made during banking services. The fourth item, which was quick financial and paperless services, had a mean of 2.75 , which was neutral, and a standard deviation of 0.664069 , which indicated a strong positive correlation. Similarly, on the item concerning increasing profits and the number of customers, the mean was 3.87 and a standard deviation of 0.709. It signals a connection between e-banking and increased benefits and customer number

This is supported by Vaidya (2011) stated that people choose mobile banking services due to their ability to check deposits, paying for a service or product offered, transferring money to another partner, and mobile banking offers an advantage in that a client can transact anywhere at any time of the day. 


\section{MInstitute Macrothink $_{\text {Int }}$}

Table 3. The Effects of Electronic Tax Towards Customer Services Delivery

\begin{tabular}{|c|c|c|c|c|c|}
\hline \multirow[t]{2}{*}{ Views of respondents } & \multicolumn{2}{|l|}{ Mean } & \multicolumn{3}{|c|}{ Std Deviation } \\
\hline & $\begin{array}{l}\text { Statistical } \\
\text { range }\end{array}$ & $\begin{array}{l}\text { Results of } \\
\text { the mean }\end{array}$ & $\begin{array}{l}\text { Statistical } \\
\text { Scales }\end{array}$ & $\begin{array}{l}\text { Results of } \\
\text { Deviation }\end{array}$ & Std \\
\hline Saving time and security of funds & 4.32 & Very strong & .91803 & $\begin{array}{l}\text { Positive and } \\
\text { high correlation }\end{array}$ & very \\
\hline $\begin{array}{l}\text { Holding a lot of financial data and } \\
\text { decreasing of financial costs }\end{array}$ & 3.97 & Strong & .74418 & $\begin{array}{l}\text { Positive and } \\
\text { correlation }\end{array}$ & high \\
\hline $\begin{array}{l}\text { Reducing financial errors and easy } \\
\text { money transfer }\end{array}$ & 4.78 & Very strong & .94312 & $\begin{array}{l}\text { Positive and } \\
\text { high correlation }\end{array}$ & very \\
\hline $\begin{array}{l}\text { Quick financial services and } \\
\text { paperless services }\end{array}$ & 4.88 & Very strong & .97194 & $\begin{array}{l}\text { Positive and } \\
\text { high correlation }\end{array}$ & very \\
\hline $\begin{array}{l}\text { Increasing of financial } \\
\text { profitability and increasing the } \\
\text { number of customers }\end{array}$ & 4.53 & Very strong & .94544 & $\begin{array}{l}\text { Positive and } \\
\text { high correlation }\end{array}$ & very \\
\hline Overall of mean & 4.35 & Very strong & -------- & -------- & \\
\hline
\end{tabular}

Source: Primary Data, 2019

Table 3 shows the results of five items examined on the influence of e-tax on delivering customer services. There was an overall mean of 4.35, which shows e-tax influences customer service in Bank of Kigali. The respondents agreed on e-tax saving time and ensuring the security of funds. The mean for this item was 4.32 and a standard deviation of 0.91803 . On holding financial data and decreasing costs, the study showed a positive relation between e-tax and customer service delivery. The mean and standard deviation were 3.97 and 0.74418 , respectively. Similarly, a mean and standard deviation of 4.78 and 0.94312 was recorded on e-tax ability to reduce financial errors and secure money transfer.

The fourth item as quick financial services and paperless services has mean of 4.88 respected by very strong with standard deviation of .97194 esteemed by positive and very high correlation and then the fifth item as increasing of financial profitability and increasing the number of customers with mean of 4.53 that stands for very strong followed by the standard deviation of .94544 respected and stands for positive and very high correlation.

This is not in any way different from Charles M. (2015), who reported that electronic tax is applied as an automated payment process that banks and corporations use allow the tax processing process to settle taxes, which is free from any human interventions businesses and corporations in paying their taxes faster than the traditional method. 


\section{Macrothink}

Enterprise Risk Management

ISSN 1937-7916

2019, Vol. 5, No. 1

Table 4. The Determinants of Customer Services Delivery Through Electronic Banking Application in Bank of Kigali

\begin{tabular}{|c|c|c|c|c|}
\hline \multirow[b]{2}{*}{ Views of respondents } & \multicolumn{2}{|l|}{ Mean } & \multicolumn{2}{|l|}{ Std Deviation } \\
\hline & $\begin{array}{l}\text { Statistical } \\
\text { range }\end{array}$ & $\begin{array}{l}\text { Results of } \\
\text { the mean }\end{array}$ & Statistical Scales & $\begin{array}{l}\text { Results of Std } \\
\text { Deviation }\end{array}$ \\
\hline $\begin{array}{l}\text { The successful quality of services } \\
\text { (customer care services) }\end{array}$ & 4.31 & Very strong & .927672 & $\begin{array}{l}\text { Positive and very } \\
\text { high correlation }\end{array}$ \\
\hline $\begin{array}{l}\text { The successful customer } \\
\text { satisfaction }\end{array}$ & 4.03 & Strong & .703962 & $\begin{array}{l}\text { Positive and high } \\
\text { correlation }\end{array}$ \\
\hline $\begin{array}{l}\text { The effective willing of customer } \\
\text { preferences }\end{array}$ & 4.06 & Strong & .708724 & $\begin{array}{l}\text { Positive and high } \\
\text { correlation }\end{array}$ \\
\hline The efficiency customer perception & 3.97 & Strong & .700227 & $\begin{array}{l}\text { Positive and high } \\
\text { correlation }\end{array}$ \\
\hline $\begin{array}{l}\text { The effective results of customer } \\
\text { expectation }\end{array}$ & 4.01 & Strong & .708181 & $\begin{array}{l}\text { Positive and high } \\
\text { correlation }\end{array}$ \\
\hline $\begin{array}{l}\text { The effective customer retention } \\
\text { management }\end{array}$ & 3.77 & Strong & .701658 & $\begin{array}{l}\text { Positive and high } \\
\text { correlation }\end{array}$ \\
\hline The transparency of services & 4.37 & Very strong & .92714 & $\begin{array}{l}\text { Positive and very } \\
\text { high correlation }\end{array}$ \\
\hline Overall of mean & 4.025 & Strong & ----- & ------ \\
\hline
\end{tabular}

Source: Primary Data, 2019

The above table 4 shows some critiques studied on determinants of customer services delivery through electronic banking application in Bank of Kigali. The results indicated a mean of 4.025, which is a reliable approximation. The first element was a successful quality of services (customer care services), and it proves strong agreement by the respondents with 4.31 as mean and 0.927672 as standard deviation. Similarly, there was successful customer satisfaction with a mean of 4.03 and a standard deviation of 0.703962 . The third item which the study aimed at proving indicated the useful willingness of customer preference maintenance, reporting a mean of 4.06 and a standard deviation of 0.708724 . The fourth item showed good customer perception recording a mean of 3.97 and 0.700227 as its standard deviation.

The fifth item indicated effective results of customer expectation, which is approved by respondents who are agreed with 4.01 as its mean and standard deviation of 0.708181 . For the sixth item on effective customer retention management, which is proved by respondents who are accepted with a mean of 3.77 with 0.701658 as its standard deviation. The seventh item was transparency of services that has a mean of 4.37 respected by very strong, followed with a standard deviation of .92714 esteemed by Positive and very high correlation.

Other studies elsewhere conducted by Tandelilin W. et al. (2007) stated that Customer service delivery is ensuring customers' satisfaction through the use of a product or service. The facility must ensure clients' expectations, preferences, and perceptions. Customer service happens 
while giving a financial service to the client. They include purchasing a product or service, and/or making a return of an item. The service can be one-on-one interaction, communication over the phone, or any other electronic means. Customer service is crucial in ensuring client retention and building sober relationships with the financial institutions.

\section{Hypotheses testing}

Estimated research hypotheses

H1: Internet banking has statistical effects towards customer services delivery.

H2: Mobile banking has statistical effects towards customer services delivery.

H3: Electronic tax has statistical effects towards customer services delivery.

Table 5. Presentation of Regression Summary

\begin{tabular}{|c|c|c|c|c|c|c|c|}
\hline \multirow[b]{2}{*}{ Model } & \multicolumn{2}{|c|}{$\begin{array}{l}\text { Unstandardized } \\
\text { Coefficients }\end{array}$} & \multirow{2}{*}{$\begin{array}{l}\text { Standardized } \\
\text { Coefficients } \\
\text { Beta }\end{array}$} & \multicolumn{2}{|c|}{$\begin{array}{l}95 \% \text { Confidence } \\
\text { Interval for B }\end{array}$} & \multicolumn{2}{|c|}{ Collinearity Statistics } \\
\hline & B & Std. Error & & $\begin{array}{l}\text { Lower } \\
\text { Bound }\end{array}$ & $\begin{array}{l}\text { Upper } \\
\text { Bound }\end{array}$ & $\begin{array}{l}\text { Tolerance/ } \\
\text { Sig. }\end{array}$ & $\mathbf{F}$ \\
\hline Constant & -3.345 & .000 & ------- & -3.345 & -3.345 & ------- & --------- \\
\hline Internet banking & .133 & .000 & .303 & .133 & .133 & .183 & 5.460 \\
\hline Mobile banking & .112 & .000 & .275 & 12.380 & 12.380 & .197 & 5.064 \\
\hline Electronic tax & .113 & .000 & .302 & .113 & .113 & .293 & 5.311 \\
\hline
\end{tabular}

Dependent variable: customer services delivery.

Based on the model coefficient result the model becomes:

$\log \mathrm{CSD}=-3.345+0.133 \mathrm{IB}_{\mathrm{t} 1}+0.112 \mathrm{MB}_{\mathrm{t} 2}+0.113 \mathrm{ET}_{\mathrm{t}}+\varepsilon_{\mathrm{t}}$;

Considering other variables stay constant then

The change of one percent (1\%) of internet banking leads to $13.3 \%$ change of customer services delivery;

The change of one percent ( $1 \%$ ) of mobile banking leads to $11.2 \%$ change of customer services delivery;

The change of one percent (1\%) of electronic tax leads to $11.3 \%$ change of customer services delivery;

\section{Conclusion}

Findings from the study suggested that the long-term consumer services delivery at Bank of 


\section{Al Macrothink}

Enterprise Risk Management

ISSN 1937-7916

2019, Vol. 5, No. 1

Kigali were explained by a probability of 0.0374 for internet banking; 0.0004 for mobile banking; and 0.0010 for electronic tax and that are respectively expected to $3.74 \% \& 0.04 \%$ \& $0.1 \%$ and of probabilities which were less than $10 \%$. Based on the regression theories, each factor of electronic banking was presenting the good fitness variability by each probability which was less than $10 \%$.

The $\mathbf{R}^{\mathbf{2}}=\mathbf{0 . 9 6 9}$ and Adjusted $\mathbf{R}^{\mathbf{2}}=\mathbf{0 . 9 6 5}$, indicated the goodness of fit of the estimated model. Up to $96.9 \%$ of long-run appreciation in customer services delivery was influenced by changes in internet banking; mobile banking; electronic tax as implemented by Bank of Kigali.

Therefore, the researcher can conclude by saying that the research hypotheses including: " $\mathbf{H}_{1}$ : internet banking has statistical effects towards customer services delivery; $\mathbf{H}_{2}$ : mobile banking has statistical effects towards customer services delivery and H3: electronic tax has statistical effects towards customer services delivery"; all were tested; verified and then they are confirmed referring to the statistical (regression analysis) findings.

For effective and resilient banking services to be adopted, the researcher suggested that Bank of Kigali work continuously with consumers in order to improve their service provisions and provide required outputs in a timely manner. This would in turn enhance performance based on the findings of obtained from the field. The leaders of Bank of Kigali, who have particularly, the electronic bank's accomplishments have been suggested the following;

1. To allow banking actors learn from each other's experiences, building on expertise and knowledge;

2. To ensure the security in electronic banking services as most if not all users expect it;

3. To uncover banking (financial) mistakes and offer ways for learning and enhancements;

4. To give an approach to survey the money related pivotal connection among implementers and recipients on the ground and decision-makers;

5. Enhance awareness among consumers regarding the use of electronic banking services through public awareness programs aimed at improving their knowledge.

\section{References}

Alexan M. (2015). "Internet banking services and the Federal Government: An Introduction", Report from the Congressional Research Service.

Allen McAndrews \& Strahan F. (2002). "Methods of internet banking services and economic growth in transition economies" (PDF). Economies of Transition.

Bahia U. (2007). Banking in the Early Stages of Industrialization: A Study in Comparative Economic History.

Barclays Bank (2013). Building the 'Go-To' bank annual: annual report 2013. London: Churchill Place. 


\section{Macrothink}

Enterprise Risk Management

ISSN 1937-7916

2019, Vol. 5, No. 1

Carlson E., \& Lang A. (2001). The Evolution of Banking in the Industrialized World Since 1800 (Princeton University Press; 2010) 384 pages. Considers how crises, bailouts, mergers, and regulations have shaped the history of banking in Western Europe, the United States, Canada, Japan, and Australia.

Charles McLure E. (2015). Investment on Mobile Money Services Anticipated to touch Micro-payment systems and their application to mobile networks.

Kigen N. (2010). New Electronic banking Management and Principals' Roles in Organizational Governance: What Can a Corporate Issue Tell us About Public Sector Management?" Public Organization Review.

Meuter D. (2010). Collecting Sales Taxes Over the Internet Explains the current rules for collecting sales tax on Internet sales.

Mulee S. (2011). Winners and Losers: Assessing the Distributional Impact of Internet banking services, CGD Working Paper No 6 (PDF). Nancy Birdsall \& John Nellis. Center for Global Development. March 9, 2006.

Munaye H. (2009). Russian Internet banking services and Corporate Governance: What Went Wrong? Stanford Law Review.

National Bank of Rwanda (2018). Financial stability: annual report 2018. Rwanda: Kigali

Ombati I., Peterson M., Onserio N., \& Richard D. (2011). Streamlined Sales Tax Project States' project to design, test and implement a sales and use tax system that radically simplifies sales and use taxes.

Safaricom limited (2016) annual Report: 2016. Westlands: Waiyaki Way.

Saleh Nsouli M. (2014). Qualitative Research Methods for the Social Sciences. Seventh Edition. Boston MA: Pearson Education Inc.

Salehi C., \& Zhila V. (2015). New Internet banking services Management and Organizational Commitment in the Public Sector: Testing a Mediation Model. International Journal of Human Resource Management.

Sathye M. (1999). Mobile Banking Trojan Bank Identified, Removed From Google Play. Digital Guardian. Retrieved 3 October 2019.

Tandelilin W., Kaaro E., Madahwartha P., \& Supriyatna A. (2007). Ericsson, Western Union partner to push mobile financial services. Mobile Payments Today. February 28, 2012.

Taylor A. (2014). The Financial and Operating Performance of Privatized Firms during the 1990s (PDF). Journal of Finance. 1999. Retrieved 31 October 2018.

Vaidya T. (2011). Mobile Payment Transaction Values for Digital and Physical Goods to Exceed \$300bn Globally Within 5 Years. Juniper Research.

Vilaet B., Ferraro R., \& Semunegus H. (2013). Congressional Intervention in State Taxation: A Normative Analysis of Three Proposals the authors analyze proposals in Congress that 
concern a moratorium on Internet access taxes, sales tax streamlining, and business activity taxes.

\section{Copyright Disclaimer}

Copyright for this article is retained by the author(s), with first publication rights granted to the journal.

This is an open-access article distributed under the terms and conditions of the Creative Commons Attribution license (http://creativecommons.org/licenses/by/3.0/). 